\title{
IMPLEMENTASI PRINSIP CORPORATE SOCIAL RESPONSIBILITY (CSR) BERDASARKAN UNDANG-UNDANG NOMOR 40 TAHUN 2007 TENTANG PERSEROAN TERBATAS
}

\author{
Marthin \\ Marthen B. Salinding \\ Inggit Akim \\ Fakultas Hukum Universitas Borneo Tarakan \\ Jl. Amal Lama No.1, Kel. Pantai Amal, Kec. Tarakan Timur, Pantai Amal, \\ Tarakan Tim., Kota Tarakan, Kalimantan Utara \\ Email :mhukum@ymail.com
}

\begin{abstract}
Abstrak
Corporate Social Responsibility (CSR) merupakan salah satu kewajiban yang harus dilaksanakan oleh perusahaan sesuai dengan isi pasal 74 Undang- Undang Nomer 40 Tahun 2007 Tentang Perseroan Terbatas (UUPT). Tujuan penelitian ini adalah untuk merumuskan alternatif bentuk-bentuk kegiatan CSR bagi perusahaan perseroan terbatas (PT) yang mengelola sumber daya alam di Kabupaten Malinau dan Tanah Tidung dan untuk mengetahui apa saja kendalakendala yang dihadapi oleh perusahaan dalam implementasinya.

Data dalam penelitian ini dianalisis secara kualitatif, yaitu data skunder yang berupa teori, definisi dan substansinya dari berbagai literatur, dan peraturan perundang-undangan, serta data primer yang diperoleh dari wawancara, observasi dan studi lapangan, kemudian dianalisis dengan undang-undang, teori dan pendapat pakar yang relevan, sehingga didapat kesimpulan tentang pelaksanaan tanggungjawab sosial perusahaan yang berkaitan dengan pengentasan masalahmasalah sosial kemasyarakatan.

Berdasarkan hasil penelitian ditemukan bahwa norma kewajiban CSR bagi perseroan terkesan tidak tegas, karena tidak memuat sanksi bagi perseroan yang melanggarnya. Pelaksanaan CSR dalam pelaksanaannya selama ini mengalami kendala karena hanya didasarkan kepada kesadaran dan komitmen perusahaan. Padahal komitmen dan kesadaran setiap perusahaan tidak sama dan sangat tergantung kepada kebijakan perusahaan masing-masing
\end{abstract}

Kata Kunci : Corporate,Responsibility, Perseroan Terbatas 


\section{PENDAHULUAN}

Corporate Social Responsibility (CSR) merupakan salah satu kewajiban yang harus dilaksanakan oleh perusahaan sesuai dengan isi pasal 74 UndangUndang Nomer 40 Tahun 2007 Tentang Perseroan Terbatas (UUPT) . Melalui undang-undang ini, industri atau koprasi-koprasi wajib untuk melaksanakanya, tetapi kewajiban ini bukan suatu beban yang memberatkan. Perlu diingat pembangunan suatu negara bukan hanya tangungjawab pemerintah dan industri saja, tetapi setiap insan manusia berperan untuk mewujudkan kesejahteraan sosial dan pengelolaan kualitas hidup masyarakat

Konsep CSR itu sendiri pertama kali dikemukakan oleh Howard R.Bowen pada tahun 1953 yang menyatakan bahwa, "it refers to the obligations of businessmen to pursue those policies, to make those decisions, or to follow those lines of action which are desireable in terms of the objectives and values of our society"1 Secara sederhana, Jhonatan Sofian menyebutkan CSR sebagai suatu konsep yang mewajibkan perusahaan untuk memenuhi dan memperhatikan kepentingan para stakeholder dalam kegiatan operasinya mencari keuntungan. Stakeholder yang dimaksud di antaranya adalah para karyawan (buruh), kostumer, masyarakat, komunitas lokal, pemerintah dan lembaga swadaya masyarakat $(\mathrm{LSM})^{2}$

Meningkatnya tingkat kepedulian kualitas kehidupan, harmonisasi sosial dan lingkungan ini juga mempengaruhi aktivitas dunia bisnis, maka, lahirlah gugatan terhadap peran perusahaan agar mempunyai tanggungjawab sosial. Disinilah salah satu manfaat yang dapat dipetik perusahaan dari kegiatan CSR. Dalam konteks inilah aktifitas CSR menjadi menu wajib bagi perusahaan, di luar kewajiban yang digariskan undang-undang. ${ }^{3}$

Ismail Solihin, Corporate Social Responsibility: from Charity to Sustainability,Salemba Empat, Jakarta, 2009, h.16

2 Jonathan Sofian Lusa, 2007, Mencari Bentuk Ideal Tanggung Jawab Sosial Perusahaan, http://jsofian.wordpress.com/2007/06/10/, Diakses pada tanggal 22 Maret 2012

3 A.B. Susanto, Corporate Social Responsibility, The Jakarta Consulting Group, Jakarta, 2007, h. 7 
Perusahaan tidak hanya dihadapkan pada tanggung jawab yang berpijak pada perolehan keuntungan/laba perusahaan semata, tetapi juga harus memperhatikan tanggung jawab sosial dan lingkungannya. Jika masyarakat (terutama masyarakat sekitar) menganggap perusahaan tidak memperhatikan aspek sosial dan lingkungannya serta tidak merasakan kontribusi secara langsung bahkan merasakan dampak negatif dari beroperasinya sebuah perusahaan maka kondisi itu akan menimbulkan resistensi masyarakat atau gejolak sosial. Komitmen perusahaan untuk berkontribusi dalam pembangunan bangsa dengan memperhatikan aspek finansial atau ekonomi, sosial, dan lingkungan itulah yang - menjadi isu utama dari konsep corporate social responsibility.

Pengaturan bagi perusahaan terhadap tanggung jawab sosial dan lingkungan (CSR) yang diatur dalam Pasal 74 UU No. 40 Tahun 2007 Tentang Perseroan Terbatas, bertujuan untuk mewujudkan pembangunan ekonomi berkelanjutan guna meningkatkan kualitas kehidupan dan lingkungan yang bermanfaat bagi Perseroan itu sendiri, komunitas setempat, dan masyarakat pada umumnya. Ketentuan ini dimaksudkan untuk mendukung terjalinnya hubungan Perseroan yang serasi, seimbang, dan sesuai dengan lingkungan, nilai, norma, dan budaya masyarakat setempat, maka ditentukanlah bahwa Perseroan yang kegiatan usahanya di bidang dan/atau berkaitan dengan sumber daya alam wajib melaksanakan tanggung jawab sosial dan lingkungan.

Untuk melaksanakan kewajiban Perseroan tersebut, maka kegiatan tanggung jawab sosial dan lingkungan harus dianggarkan dan diperhitungkan sebagai biaya Perseroan yang dilaksanakan dengan memperhatikan kepatutan dan kewajaran. Kegiatan tersebut harus dimuat dalam laporan tahunan Perseroan. Dan dalam hal Perseroan tidak melaksanakan tanggung jawab sosial dan lingkungan, maka Perseroan yang bersangkutan akan dikenai sanksi sesuai dengan ketentuan peraturan perundang-undangan.

Namun demikian kenyataan menunjukkan bahwa pelaksanaan CSR sebagai kewajiban hukum perseroan masih terkesan asal-asalan, dan belum menyentuh kepentingan masyarakat secara optimal. Ke depan Tanggung Jawab Sosial Perusahaan, apabila dilaksanakan dengan benar, akan memberikan dampak positif 
bagi perusahaan, lingkungan, termasuk sumber daya manusia, sumber daya alam dan seluruh pemangku kepentingan dalam masyarakat. Perusahaan yang mampu sebagai penyerap tenaga kerja, mempunyai kemampuan memberikan peningkatan daya beli masyarakat, yang secara langsung atau tidak, dapat mewujudkan pertumbuhan lingkungan dan seterusnya. Mengingat kegiatan perusahaan itu sifatnya simultan, maka keberadaan perusahaan yang taat lingkungan akan lebih bermakna.

Pentingnya penelitian ini dilakukan dengan keutamaan untuk dapat menggali lebih dalam dan mengetahui masalah-masalah yang dihadapi dalam mengimplementasi CSR oleh perusahaan di Kabupaten Malinau sehingga manfaatnya belum maksimal bagi masyarakat dan lingkungan. Identifikasi masalah-masalah tersebut menjadi bahan evaluasi prioritas yang berkaitan dengan penerapan CSR.

Berdasarkan penjelasan di atas maka penelitian ini akan membahas pengaturan CSR dalam Undang-undang No. 40 Tahun 2007 tentang Perseroan Terbatas (PT) terhadap perseroan yang mengelola sumber daya alam dan kendala dalam mengimplementasikan ketentuan Pasal 74 Undang-undang No. 40 Tahun 2007 Tentang Perseroan Terbatas.

\section{HASIL DAN PEMBAHASAN}

Substansi keberadaan Prinsip Tanggung Jawab Sosial dan Lingkungan bagi Perusahaan (Corporate Social Responsibility; selanjutnya disebut CSR), adalah dalam rangka memperkuat kemampuan perusahaan untuk beradaptasi dengan lingkungannya, komunitas dan stakeholder yang terkait dengannya, baik lokal, nasioal, maupun global. Di dalam pengimplementasiaannya, diharapakan agar unsur-unsur perusahaan, pemerintah dan masyarakat saling berinteraksi dan mendukung, supaya CSR dapat diwujudkan secara komprehensif, sehingga dalam pengambilan keputusan, menjalankan keputusan, dan pertanggungjawabannya dapat dilaksanakan bersama.

Penerapan kegiatan CSR di Indonesia baru dimulai pada awal tahun 2000, walaupun kegiatan dengan esensi dasar yang sama telah berjalan sejak tahun 1970-an, dengan tingkat yang bervariasi, mulai dari yang paling sederhana seperti 
donasi sampai kepada yang komprehensif seperti terintegrasi ke dalam strategi perusahaan dalam mengoperasikan usahanya. Menyadari pentingnya suatu tanggung jawab sosial (CSR), maka dalam penerapan CSR diperlukan suatu law enforcement untuk mengatur bagaimana ketentuan penerapannya. Berikut adalah peraturan yang mendukung pelaksanaan CSR di Indonesia, yakni :

a. Undang-Undang Nomor 40 Tahun 2007 Tentang Perseroan Terbatas (UUPT)

Tanggung jawab sosial dan lingkungan perseroan diatur dalam Pasal 74 yang menjelaskan sebagi berikut; (1) Perseroan yang menjalankan kegiatan usahanya di bidang dan/atau berkaitan dengan sumber daya alam wajib melaksanakan tanggung jawab sosial dan lingkungan; (2) Tanggung jawab sosial dan lingkungan sebagaimana dimaksud pada ayat (1) merupakan kewajiban Perseroan yang dianggarkan dan diperhitungkan sebagai biaya Perseroan yang pelaksanaannya dilakukan dengan memperhatikan kepatutan dan kewajaran; (3) Perseroan yang tidak melaksanakan kewajiban sebagaimana dimaksud pada ayat (1) dikenai sanksi sesuai dengan ketentuan peraturan perundang-undangan; (4) Ketentuan lebih lanjut mengenai tanggung jawab sosial dan lingkungan diatur dengan Peraturan Pemerintah.

Namun dalam pengaturan dan ketentuan dari CSR ini dianggap masih terdapat kerancuan jika kita menelaah lebih lanjut Pasal 74. Hal ini dapat dilihat pada kalimat "wajib bagi perseroan yang menjalankan kegiatan usahanya dalam mengelola atau yang berkaitan dengan sumber daya alam”, disini CSR cenderung dianggap hanya sebuah kewajiban bagi perseroan yang berkegiatan usaha mengolah atau yang berkaitan dengan sumber daya alam saja, sedangkan perseroan diluar usaha tersebut tidak diwajibkan.

Persoalan berikutnya, mengenai anggaran CSR yang dilakukan dengan memperhatikan kepatutan dan kewajaran sedangkan nilai patut dan wajar suatu perusahaan tidak sama dengan perusahaan lain, maka batasan nilai patut dan wajar ini belum bisa dijadikan acuan konkrit perusahaan dalam mengimplementasikan program CSR.

Kerancuan ketiga yaitu adanya ketidakjelasan sanksi bagi yang tidak melaksanakannya, ketentuan sanksi yang dimaksud itu tidak dijelaskan 
mengacu pada Peraturan yang mana. Hal ini mengakibatkan terjadinya pro dan kontra pada kalangan pengusaha.

Kerancuan yang terjadi pada pasal 74 ini sudah pernah diajukan oleh berbagai organisasi pengusaha di Indonesia seperti KADIN, IWAPI untuk Uji Material (judicial review) kepada Mahkamah Konstitusi (MK). Mengenai hal ini MK sendiri memberikan penolakan Uji Material terhadap pasal 74 ayat 1,2, dan 3. Alasan MK menolak adalah karena program CSR tidak bertentangan dengan pasal 33 UUD 1945 dan Majelis melindungi hak kontitusional warga yang berada di lingkungan perusahaan dengan mewajibkan perusahaan yang diuntungkan untuk membagi kekayaan untuk kemakmuran rakyat. ${ }^{4}$

b. Undang-Undang Nomor 25 Tahun 2007 Tentang Penanaman Modal (UUPM) Pengaturan CSR dalam UUPM, terdapat dalam beberapa pasal yaitu :

1) Pasal 15 huruf (b),'Setiap penanam modal berkewajiban untuk melaksanakan tanggung jawab sosial perusahaan"

2) Pasal 16 huruf (d)," Setiap penanam modal bertanggung jawab menjaga kelestarian lingkungan hidup"

3) Pasal 16 huruf (e), Setiap penanam modal bertanggung jawab menciptakan keselamatan, kesehatan, kenyamanan, dan kesejahteraan pekerja

4) Pasal 17,

Penanam modal yang mengusahakan sumber daya alam yang tidak terbarukan wajib mengalokasikan dana secara bertahap untuk pemulihan lokasi yang memenuhi standar kelayakan lingkungan hidup, yang pelaksanaannya diatur sesuai dengan ketentuan peraturan perundangundangan

Adanya Undang-Undang Nomor 25 Tahun 2007 di dalam asas-asasnya disebutkan mengenai asas akuntabilitas, yaitu di dalam penyelenggaraan penanaman modal harus dipertanggung jawabkan kepada masyarakat atau rakyat sebagai pemegang kedaulatan negara. Disebutkan juga mengenai asas

4[ Rosady Ruslan, "Permasalahan Corporate Social Responsibility di Indonesia", www.rosadyruslan-humas.blogspot.com, akses Januari 2013. 
keberlanjutan yaitu mengenai penanaman modal untuk menjamin kesejahteraan dan kemajuan dalam segala aspek kehidupan untuk masa kini dan masa yang akan datang. Ada juga mengenai asas berwawasan lingkungan yaitu investor harus memperhatikan dan mengutamakan perlindungan dan pemeliharaan lingkungan hidup.

Sejalan dengan hal tersebut, maka ketentuan mengenai CSR sudah merupakan kewajiban bagi investor yang ingin menanamkan modalnya pada sektor pertambangan mineral dan batubara di Indonesia. Tanggung jawab sosial perusahaan terhadap masyarakat hukum adat berkaitan dengan teori utilitarisme sebagaimana yang diutarakan oleh Jeremy Bentham, dikutip Ahmad Ali mengatakan, adanya negara dan hukum semata-mata hanya demi manfaat sejati, yaitu kebahagiaan mayoritas rakyat. ${ }^{5}$ Curzon mengatakan bahwa: Utilitarianism is a moral philosophy that defines the rightness of an action in terms of its contribution to general happines and considers ultimate good to be the greatest happinest of the greatest number. ${ }^{6}$

Pada dasarnya doktrin tersebut menganjurkan the gretatest happines principle atau prinsip kebahagiaan semaksimal mungkin. ${ }^{7}$ Menurut teori ini masyarakat yang ideal adalah masyarakat yang mencoba kebahagiaan dan memperkecil ketidakbahagiaan atau masyarakat yang mencoba memberi kebahagiaan yang sebesar mungkin kepada rakyat pada umumnya dan agar ketidakbahagiaan di usahakan sesedikit mungkin oleh rakyat pada umumnya tadi. Kebahagiaan berarti kesenangan atau tidak sengsara, dan ketidak bahagiaan berarti kesengsaraan atau ketiadasenangan. ${ }^{8}$

Utilitarisme disebut juga sebagai teori teleologis (dari kata Yunani, telos =tujuan), sebab menurut teori ini kualitas etis suatu perbuatan diperoleh dengan

${ }^{5}$ Achmad Ali, Menguak Tabir Hukum (Suatu Kajian Filosofis dan Sosiologis). Toko Gunung Agung Jakarta, 2002, h. 76.

${ }^{6}$ L.B. Curzon, Jurisprudence, M \& E. Hard Book, 1997, h. 93-94.

${ }^{7}$ Achmad Ali, Op.Cit. h. 76

${ }^{8}$ Ibid, h. 76-77. 
dicapainya tujuan perbuatan. Perbuatan yang memang bermaksud baik tetapi tidak menghasilkan apa-apa, menurut utilitarisme tidak pantas disebut baik. ${ }^{9}$

Menurut teori ini perbuatan yang sempat mengakibatkan paling banyak orang merasa senang dan puas adalah perbuatan yang terbaik. Mengapa melestarikan lingkungan hidup, misalnya, merupakan tanggung jawab moral kita? Utilitarisme menjawab karena hal itu membawa manfaat paling besar bagi umat manusia sebagai keseluruhan, termasuk juga generasi-generasi sesudah kita. Menurut utilitarisme sebagai upaya pembangunan berkelanjutan (sustainable development) menjadi tanggung jawab moral kita. ${ }^{10}$

Berdasarkan uraian tentang konsep perusahaan maka paradigma tradisional perusahaan sudah dianggap tidak relevan lagi. Perusahaan modern sebagai suatu perusahaan yang menjaga keseimbangan antara kepentingan ekonomi dan kepentingan sosial serta lingkungan merupakan prinsip utama saat ini. Hal ini secara tidak langsung telah mempengaruhi kedudukan CSR itu sendiri di mata pengusaha. Pergeseran paradigma tanggung jawab perusahaan dan perkembangan tentang penerapan CSR dewasa ini semakin menunjukan pentingnya peranan perusahaan dalam menjaga kelestarian lingkungan dan kesejahteraan masyarakat, selain kewajibannya kepada pemegang saham.

Perusahaan merupakan keluarga besar yang memiliki tujuan dan target yang hendak dicapai, yang berada di tengah lingkungan masyarakat yang lebih besar. Sebagai warga masyarakat, perusahaan membutuhkan apresiasi dan interaksi anggota masyarakat dalam setiap aktivitasnya. Gambaran mengenai kedudukan perusahaan sebagai bagian dari masyarakat yang lebih luas (stakeholders) dapat dilihat dari bagan yang dijelaskan oleh Nor Hadi yang sejalan dengan pendapat Archie B. Caroll. ${ }^{11}$ Perusahaan dalam menjalankan operasionalnya mempunyai empat tanggung jawab terhadap masyarakat luas

9 K. Bertens, Pengantar Etika Bisnis (Seri Filsafat Atmajaya, Kanisius, Yogyakarta, 2000. h. 67

10 Ibid. h.. 66

11 Archie B. Carrol berpendapat bahwa konsep CSR memuat komponen-komponen sebagai berikut: Economic Responsibilities, Legal Responsibilities, Ethical Responsibilities dan Discretionary Responsibilities. Lihat Dwi Kartini, Corporate Social Responsibility: Transformasi Konsep Sustainability Management Dan Implementasi Di Indonesia, Refika Aditama, 2009, Bandung, h 14. 
yaitu $^{12}$; (a) Tanggung jawab ekonomis; (b) Tanggung jawab legal; (c) Tanggung jawab etis; (d) Tanggung jawab filantropis

Tanggung jawab ekonomi, keberadaan perusahaan yang selama ini hanya ditujukan untuk memperoleh keuntungan dalam menjaga keberlangsungan perusahaan, serta meningkatkan kesejahteraan bagi para pemilik (shareholders). Untuk itu, perusahaan memiliki tanggung jawab menjamin dan meningkatkan kesejahteraan bagi pemegang saham.

Tanggung jawab legal, perusahaan sebagai bagian dari masyarakat yang lebih luas memiliki kepentingan untuk memenuhi aturan formal, sebagaimana yang diisyaratkan oleh pemerintah. Operasional perusahaan hendaknya dilakukan sesuai dengan kaidah peraturan perundangan.

c. Undang-Undang Nomor 4 Tahun 2009 Tentang Pertambangan Mineral dan Batubara (Minerba).

Pada Undang-Undang Minerba ini penjelasan yang berkaitan dengan CSR terdapat pada : (1) Pasal 95 huruf (d), Pemegang Izin Usaha Pertambangan (IUP) dan IUPK wajib melaksanakan pengembangan dan pemberdayaan masyarakat setempat; (2) Pasal 106, Pemegang IUP dan IUPK harus mengutamakan pemanfaatan tenaga kerja setempat, barang, dan jasa dalam negeri sesuai ketentuan perundang-undangan; (3) Pasal 107, Dalam melakukan kegiatan operasi produksi, badan usaha pemegang IUP dan IUPK wajib mengikutsertakan pengusaha lokal yang ada di daerah tersebut sesuai dengan peraturan perundang undangan.

Dalam Undang-Undang Minerba, CSR ditunjukkan dalam bentuk pengembangan dan pemberdayaan masyarakat setempat, pemanfaatan tenaga kerja dan pengikutsertaan pengusaha lokal. Keberadaan perusahaan pertambangan idealnya bermanfaat tidak hanya bagi perusahaan secara internal, melainkan membawa dampak positif bagi masyarakat hukum adat . prinsip dasar CSR adalah memberdayakan masyarakat sekitar yang notabene miskin agar terbebas dari kemiskinan. Harapan dari pelaksanaan CSR selain memberdayakan masyarakat, dari sisi perusahaan, agar operasional berjalan lancar tanpa gangguan. Jika

${ }^{12}$ Nor Hadi, Corporate Social Responsibility, Graha Ilmu, Yogyakarta, 2011, h. 35. 
hubungan antara perusahaan dan masyarakat hukum adat tidak baik, maka dapat dipastikan akan timbul masalah dalam aktivitas perusahaan, terutama dalam pelaksanaan CSR yang hingga saat ini pengetahuan serta perhatian masyarakat masih minim.

Idealnya adalah bahwa tujuan dan manfaat penerapan CSR oleh perusahaan pertambangan mineral dan batubara adalah membawa dampak yang positif bagi masyarakat hukum adat atau komunitas setempat melalui berbagai program pemberdayaan, sedangkan secara tidak langsung, keberhasilan pelaksanaan CSR akan berdampak positif pada citra perusahaan sehingga keuntungan pun akan meningkat, walaupun tidak secepat yang diinginkan. Dengan demikian dapat dijelaskan bahwa prinsip CSR merupakan bentuk pengelolaan mineral dan batubara yang berpihak kepada masyarakat hukum adat.

\section{a. Pelaksanaan CSR}

Di dalam prakteknya, penerapan CSR disesuaikan dengan kemampuan masing-masing perusahaan dan kebutuhan masyarakat. Oleh karena itu, kegiatan CSR sangat beragam. Hal ini bergantung pada proses interaksi sosial, bersifat sukarela didasarkan pada dorongan moral dan etika, dan biasanya melebihi dari hanya sekedar kewajiban memenuhi peraturan perundang-undangan.

Perusahaan yang termasuk dalam subjek penelitian ini ialah PT Bara Dinamika Muda Sukses (BDMS)dimana kegiatan usahanya adalah eksplorasi dan eksploitasi batubara di Desa Loreh dan Desa Langap, Keamatan Loreh Kabupaten Malinau Provinsi Kalimantan Utara.

Untuk menindaklanjuti pelaksanaan CSR maka perusahaan telah melakukan berbagai upaya dalam pengelolaan lingkungan. Penelitian ini menitikberatkan kepada beberapa bentuk CSR sebagai wujud tanggung jawab sosial dab lingkungan hidup yang dilakukan oleh perusahaan terhadap masyarakat di Desa Loreh dan Desa Langap

Sebagai agent of development, perusahaan merupakan bagian dari masyarakat atau warga negara. Dengan menjadi bagian dari warga negara suatu bangsa (corporate citizenship),8 maka perusahaan juga mempunyai kewajiban dalam pembangunan. Beberapa bentuk CSR yang telah dilakukan oleh perusahaan 
dalam rangka pemenuhan tanggung jawab sosial dan lingkungan hidup di Desa Loreh dan dan Desa Langap yang akan diuraikan sebagai berikut:

\section{1) Peluang Usaha bagi Masyarakat}

Pada saat dilakukan penelitian ini, diketahui adanya peluang usaha di sekitar lokasi operasional perusahaan. Salah satunya adalah adanya usaha lokal masyarakat sekitar dalam penyediaan jasa dan pemenuhan kebutuhan sehari-hari pekerja, seperti; membuka rumah kos-kosan bagi karyawan, penginapan, rental mobil,tukang ojek, tukang kayu dan beberapa warung di sekitar lokasi kegiatan. Se;ain itu masyarakat menjual langsungsung hasil kebun seperti buah-buahan dan syur-sayuran kepada perusahaan.

\section{2) Membuka Akses Jalan}

Jalan sebagai bagian sistem transportasi nasional mempunyai peranan penting terutama dalam mendukung ekonomi, sosial budaya, lingkungan, politik, serta pertahanan dan keamanan. Dari aspek ekonomi, jalan sebagai modal sosial masyarakat merupakan katalisator di antara proses produksi, pasar, dan konsumen akhir. Dari aspek sosial budaya, keberadaan jalan membuka cakrawala masyarakat yang dapat menjadi wahana perubahan sosial, membangun toleransi, dan mencairkan sekat budaya. Dari aspek lingkungan, keberadaan jalan diperlukan untuk mendukung pembangunan berkelanjutan ${ }^{13}$

Sebelum perusahaan PT.BDMS dibuka di Desa Loreh dan Langap sekitar tahun 1993, satu-satunya akses transportasi yang menhubungkan Desea Loreh dengan daerah lain seperti Kota Malinau adalah transportasi sungai. Tentunya hal ini membutuhkan waktu yang lama dan biaya yang besar. Disamping itu transportasi tersebut diprngaruhi oleh alam. Ada kalah kalahnya masyarakat setempat tidak bisa keluar kareana banjir ataupun karena debit air terlalu kering sehing tidak dimungkinkan dilalui transportasi sungai. Akibatnya harga kebutuhan pokok sangat mahal, seterusnya mempengaruhi tingkat kesejahteraan masyarakat.

Setelah eksplorasi dan eksploitasi sumber daya mineral dan batubara oleh PT. BDMS, perusahaan membuka akses jalan darat yang menghubungkan Kota

${ }^{13}$ Alinea ke-4 Penjelasan Undang-Undang Nomor 38 Tahun 2004 tentang Jalan (Lembaran Negara Republik Indonesia Tahun 2004 Nomor 132Tambahan Lembaran Negara Republik Indonesia Nomor 132). 
Malinau dengan Drsa Loreh dan Desa Langap merubah secara total keadaan geografis kedua desa tersebut yang sebelumnya terisolir kini telah dilalui kendaraan roda empat dan roda dua. Dengan adanya akses jalan darat, masyarakat dikedua Desa dengan leuasa pergi ke Malinau Membeli kebutuhan pokok dan bahan bangunan $<$ Harga kebutuhan pokok telah terjangkau oleh masyarakat. Tentunya mempengaruhi tingkat kesejahteraan masyarakat, hali dapat dilihat dengan jelas dengan bangunan-bangunan masyarakat besar-besar dan cantikcantik. Sesuai dengan pakta yang dilihat oleh penelitih dikedua desa tersebut tidak terlihat adanya rumah kumuh. Bahkan terlihat banyak rumah beton.

Disamping itu sebagai bentuk kepedulian Perusahaan kepada masyarakat perusahaan juga membuat akses jalan ke kebun masyarakat. Menurut Kepala Desa Loreh, Mika Jalai ${ }^{14}$ dengan adanya jalan ke kebun, jelas mempermudah masyarakat pergi ke kebun dengan menggunakan kendaraan,

Namun demikian adanya akses jalan darat yang dilalui oleh kendaraan perusahaan dan kendaraan umum membawah dampak negatif bagi lengkungan dan masyarakat. Jika hujan tidak turun dalam satu hari saja, maka sedua desa tersebut diselimuti oleh debu. Menururt salah seorang Tokoh Masyarakat Desa Langap, Aran Alang ${ }^{15}$ bahwa dalam rangkah mengurangi dampak dari debu, pihak perusahaan melakukan penyiraman jalan, namun hal tersebut tidak rutin dilakukan. Tentunya implikasinya terhadap kualitas kesehatan masyarakat dan kualitas lingkungan hidup.

\section{3) Pemberian Fasilitas Kesehatan Masyarakat}

Dalam rangka meningkatkan derajat kesehatan masyarakat, perlu dilaksanakan berbagai upaya kesehatan termasuk pengawasan kualitas air yang di konsumsi oleh masyarakat. Kebutuhan masyarakat terhadap air yang semakin meningkat mendorong lebih menguatnya nilai ekonomi air dibanding nilai dan fungsi sosialnya. Kondisi tersebut berpotensi menimbulkan konflik kepentingan antar sektor, antar wilayah dan berbagai pihak yang terkait dengan sumber daya air.

\footnotetext{
${ }^{14}$ Mika Jalai Kepala Desa Loreh, Wawancara tanggal 20 Juni 2016

${ }^{15}$ Arang Alang Tokoh Masyarakat Desa Langap, Wawancara tanggal Juni 2016
} 
Kualitas air yang digunakan masyarakat untuk memasak, minum, mandi dan kebutuhan sehari-hari lainnya harus memenuhi syarat kesehatan agar terhindar dari gangguan kesehatan yang artinya kualifikasi air yang digunakan tersebut harus bersih. Dalam Peraturan Menteri Kesehatan No. 416 Tahun 1990 disebutkan bahwa air bersih adalah air yang digunakan untuk keperluan seharihari yang kualitasnya memenuhi syarat kesehatan dan dapat diminum apabila telah dimasak. Kualitas air juga harus memenuhi syarat kesehatan yang meliputi persyaratan mikrobiologi, fisika kimia, dan radioaktif.

Kehadiran Pertambangan Batubara di Desa Loreh dan Desa Langap tentunya mempengaruhi kualitas air khusunya air sungai yang ada disekitar wilayah pertambangan yang sebelumnya merupakan sumber air minum, mandi dan cuci masyarakat setempat. Sebagai bentuk tanggung jawab sosial dan lingkungan, maka PT BDMS membuat pipanisasi di kedua desa tersebut dengan mengambil air dari sumber mata air yang tidak tercemar oleh dampak pertambangan batubara. Selanjutnya air tersebut disalurkan ke kesetiap rumah di Desa Loreh dan Desa Langap. Disamping itu setiap rumah diberikan propil Tank sebagai tempat penampungan air bersih. ${ }^{16}$

Bantuan sumber air bersih, membantu masyarakat untuk mendapatkan akses sumber air bersih untuk keperluan sehari-hari. Air bersih menjadi kebutuhan masyarakat untuk keperluan sehari-hari seperti mandi, memasak, dan mencuci. Selama ini Desa Lore mengalami kesulitan mendapatkan sumber air bersih karena air yang selama ini digunakan adalah air sungai yang tidak layak oleh karena itu perusahaan memberikan bantuan berupa sumber air bersih kepada masyarakat. Untuk itu kualitas air yang berhubungan dengan kesehatan yang telah ada perlu disesuaikan dengan perkembangan teknologi.

\section{4) Rekrutmen Tenaga Kerja Lokal sebagai Tenaga Kerja}

Kehadiran perusahaan haruslah mampu memberikan dampak yang baik kepada masyarakat, kepedulian perusahaan terhadap masyarakat tidak hanya sebatas pemberdayaan masyarakat yang terbatas hanya pada satu aspek saja, tetapi

\footnotetext{
${ }^{16}$ Dharma Azrevi Rangkuti, Kabag Departement CSR PT.BDMS, wawancara tanggal 20 Juni 2016
} 
juga perusahaan ikut serta dalam menyukseskan pembangunan daerah, termasuk memberdayakan tenaga kerja lokal. PT. BDMS wajib mengutamakan pemanfaatan tenaga kerja setempat dan bertanggung jawab dalam mengembangkan lingkungan dan masyarakat setempat. Dengan kata lain perusahaan wajib mempekerjakan tenaga kerja setempat dalam jumlah dan kualitas tertentu, serta meningkatkan lingkungan hunian masyarakat, agar tercipta keharmonisan antara perusahaan dengan masyarakat sekitarnya. Menurut Kepalah Desa Loreh, Mika Jalai ${ }^{17}$ Tenaga kerja lokal yang tidak memiliki skil tertentu di kirim oleh perusahaan ke Balikpapan selama waktu tertentu untuk menjalani training.

Dalam hal perekrutan tenaga kerja lokal pihak perusahaan sudah menunjukkan ke arah komitmen dalam merekrut tenaga kerja di Desa Loreh dan Desa Langap . Kesempatan kerja yang diberikan kepada masyarakat sekitar pada umumnya berasal dari jenis pekerjaan yang bersifat non skill, seperti: tenaga keamanan, helper, cleaning service, catering, dan sebagainya yang direkrut oleh perusahaan outsourcing yang merupakan sub-kontraktor dari perusahaan. Sementara untuk tenaga kerja yang membutuhkan tenaga skill sebagian besar telah disediakan oleh kontraktor sendiri.

\section{5) Bantuan Fasilitas Pendidikan}

Setiap perusahaan dalam menjalankan kelangsungan perusahaannya tidak hanya memaksimalkan laba yang diperolehnya, tetapi diperlukan sebuah tanggung jawab sosial berupa kewajiban - kewajiban Terhaap pihak lain. Keberadaan CSR (Corporate Social Responsibility) di Indonesia memperoleh respon yang positif dari pemerintah. Tanggung jawab sosial dan lingkungan perusahaan (CSR) di bidang pendidikan selain dapat meningkatnya citra sebuah perusahaan, juga dapat membuktikan bahwa perusahaan tersebut turut memikirkan nasib generasi bangsa, dan mampu menjadi warga negara yang baik. Arah implementasi CSR pada bidang pendidikan makin terasa diwujudkan oleh berbagai perusahaan dewasa ini. Alasan manajemen perusahaan NDMS memfokuskan program CSR nya ke dunia pendidikan dikarenakan fakta bahwa sarana dan prasarana pendidikan masih

${ }^{17}$ Mika Jalai, Kepala Desa Loreh, Wawancara tanggal 20 Juni 2016 
memprihatinkan, dan kesadaran tentang diperlukannya SDM handal yang dari pendidikan yang memadai. Dalam pelaksanaan pemberian fasilitas pendidikan bagi masyarakat, perusahaan memberikan buku buku pelajaranan bagi anak-anak sekolah dasar setempat guna memperkaya ilmu pengetahuan umum mereka yang juga dimaksudkan sebagai penunjang pelajaranpelajaran inti sekolah. Selain itu perusahaan juga menyumbangkan buku tulis untuk dibagikan di sekolah-sekolah sekitar wilayah operasi di Desa Lore dan Desa Langap,

Selain bantuan buku, menurut Sekdes Desa Langap Samuel Bilung ${ }^{18}$ PT. BDMS juga membangun rumah belajar di Desa Langap (Rumah Bio) dan Desa Loreh(rumah Tio). Hal yang senada dikemukakan juga oleh Kepala Desa Loreh Rumah belajar dikelola oleh karyawan PT. BDMS bekerja sama dengan Pemuda Desa.

\section{6) Pemberian Bahan Bakar Solar}

Kekurangan daya listrik dari Perusahaan Listrik Negara (PLN), merupakan salah satu masalah utama di wilayah pedalaman Indonesia, termasuk di Kabupaten Malinau, Provinsi Kalimantan Utara. Termasuk dalam hal ini adalah Desa Loreh dan Desa Langap hingga saat ini belum terjangkau layanan litrik dari PLN.

Menyadari listrik merupakan salah satu kebutuhan dasar masyarakat, PT BDMS, sebuah perusahaan tambang batu bara yang beroperasi di Desa Loreh dan Desa Langap Kabupaten Malinau, turut berperan menyediakan bahan bakar solar untuk bahan bakar genset sebesar 4.000 liter per bulan bagi masing-masing Desa

Kabag Departement CSR BDMS Dharma Azrevi Rangkuti mengatakan, hal itu merupakan salah satu dukungan perusahaan untuk meningkatkan kualitas hidup masyarakat sekitar perusahaan. "Perusahaan menyadari, listrik sangat bermanfaat dan telah menjadi kebutuhan dasar masyarakat.Jadi, kepedulian akan kebutuhan ini kami wujudkan dengan turut menyediakan daya listrik bagi peningkatkan kualitas hidup masyarakat,"19

\footnotetext{
${ }^{18}$ Samuel Bilung, Sekdes Desa Langap, Wawancara tanggal 20 Juni 2016

${ }^{19}$ Dharma Asrevi RangkutiKabag Depertement CSR PT BDMS, wawancara tanggal 20 Juni 2016
} 
Sekeretaris Desa Langgap secara khusus menyampaikan terimakasih kepada BDMS atas kepeduliannya menyediakan bahan bakar lolar bagi mesin genset lengkap dengan fasilitas pendukungnya, sehingga warga di Desa Loreh dan Desa Langap bisa merasakan listrik. ${ }^{20 ،}$

\section{Hal-Hal yang Menjadi Kendala dalam Mengimplementasikan Ketentuan Pasal 74 Undang-undang No 40 Tentang Perseroan}

Pelaksanaan CSR selama ini hanya didasarkan kepada kesadaran dan komitmen perusahaan. Padahal komitmen dan kesadaran setiap perusahaan tidak sama dan sangat tergantung sekali kepada kebijakan perusahaan masing-masing. Menggantungkan pelaksanaan CSR kepada kesadaran dan komitmen perusahaan mempunyai beberapa kelemahan. Kelemahan paling mendasar adalah tidak adanya sanksi yang tegas bagi perusahaan yang tidak melaksanakan CSR. Kondisi ini tidak akan mendorong pelaksanaan CSR di Indonesia. Selama ini juga, bagi perusahaan yang melaksanakan CSR tidak memilki arah yang jelas. Padahal ada banyak sekali manfaat yang diperoleh apabila CSR dilaksanakan dengan aturan dan arahan yang jelas

Baik Pasal 74 ayat (3) UU PT maupun Pasal 2 PP Nomor 47 Tahun 2012 tidak secara tegas menentukan wujud dan sanksi hukum bagi sebuah perusahaan yang dengan sengaja tidak melaksanakan kewajiban CSR. Kedua peraturan tersebut mengatur mengenai kewajiban hukum bagi perusahaan untuk menjalankan tanggung jawab sosial (CSR) yang berkaitan dengan sumber daya alam. Adapun ketentuan Pasal 74 ayat (1) UU PT menyatakan, perseroan dalam menjalankan kegiatan usahanya di bidang dan/ atau berkaitan dengan sumber daya alam wajib melaksanakan tanggung jawab sosial dan lingkungan. Ketentuan Pasal ini mengatur mengenai kewajiban hukum yang harus dilaksanakan oleh sebuah perusahaan karena $C S R$ dalam ketentuan Pasal 74 ayat (1) UU PT telah ditetapkan sebagai kewajiban hukum. Hal ini disebabkan banyaknya sorotan terhadap dunia usaha dalam menjalankan bisnisnya, seperti etika yang harus dijalankan dalam berbisnis, memperhatikan keseimbangan lingkungan terhadap lingkungan di sekitarnya adalah merupakan suatu upaya penting bagi pelaku bisnis agar

20 Samuel Bilung Sekdes Desa Langap wawanvara tanggal 20 Juni 2016 
melaksanakan CSR ini bukan sebagai kewajiban moral semata yang pelaksanaannya bersifat sukarela.

Dimasukkannya CSR dalam Pasal 74 ayat (1) UU PT sebagai kewajiban hukum merupakan suatu langkah maju. Akan tetapi ketentuan tersebut UUPT dan PP tidak ada artinya apabila tidak mengatur sanksi hukum yang dapat memaksa terhadap perusahaan yang tidak melaksanakan pasal tersebut. Kedua aturan tersebut tidak mengatur sanksi atas tidak dilaksanakannya CSR akan berimbas pada banyaknya perusahaan yang akan mengabaikan ketentuan CSR ini apabila tidak ada aturan yang memaksanya dan akan menjadi kendala dalam mengimplementasikan ketentuan $C S R$ ini dalam praktik.

Dari ketentuan tersebut diatur mengenai sanksi hukum bagi perusahaan yang tidak melaksanakan kewajiban tanggung jawab sosial dan lingkungan. Namun, ketentuan tersebut tidak mengatur secara tegas apa wujud dari sanksi dalam Pasal 74 ayat (3) UU PT tersebut. Apabila dicermati, Pasal 74 ayat (4) UU PT menyatakan bahwa ketentuan lebih lanjut mengenai tanggungjawab sosial dan lingkungan diatur dengan peraturan pemerintah. Adapaun PP yang dimaksud Peraturan Pemerintah Nomor 47 Tahun 2012. Dalam PP tersebut tidak mengatur secara tegas apa wujud dari sanksi hukumnya.

Dalam Pasal 2 PP Nomor 47 Tahun 2012 menyatakan setiap perseroan selaku subjek hukum mempunyai tanggung jawab sosial dan lingkungan. Pasal 3 ayat (1) menyatakan tanggung jawab sosial dan lingkungan sebagaimana dimaksud dalam Pasal 2 menjadi kewajiban bagi Perseroan yang menjalankan kegiatan usahanya di bidang dan/atau berkaitan dengan sumber daya alam berdasarkan Undang- Undang. Kewajibannya dilaksanakan baik di dalam maupun di luar lingkungan. Dalam Pasal 4 ayat (1) menyebutkan, tanggung jawab sosial dan lingkungan dilaksanakan oleh Direksi berdasarkan rencana kerja tahuna Perseroan setelah mendapat persetujuan Dewan Komisaris atau RUPS sesuai dengan anggaran dasar Perseroan, kecuali ditentukan lain dalam peraturan perundang-undangan Ayat (2) Rencana kerja tahunan Perseroan sebagaimana dimaksud pada ayat (1) memuat rencana kegiatan dan anggaran yang dibutuhkan untuk pelaksanaan tanggung jawab sosial dan lingkungan. Pasal 5 ayat (1) 
Perseroan yang menjalankan kegiatan usahanya di bidang dan/ atau berkaitan dengan sumber daya alam, dalam menyusun dan menetapkan rencana kegiatan dan anggaran sebagaimana dimaksud dalam Pasal 4 ayat (2) harus memperhatikan kepatutan dan kewajaran. Ayat (2) Realisasi anggaran untuk pelaksanaan tanggung jawab sosial dan lingkungan yang dilaksanakan oleh Perseroan sebagaimana dimaksud pada ayat (1) diperhitungkan sebagai biaya Perseroan. Pasal 6 Pelaksanaan tanggung jawab sosial dan lingkungan dimuat dalam laporan tahunan Perseroan dan dipertanggungjawabkan kepada RUPS.

Pasal 74 UU PT jo PP 47 Tahun Pasal 1 angka 3 UU PT menyatakan, setiap perusahaan wajib menerapkan prinsip tata kelola perusahaan yang baik dan melaksanakan tanggungjawab sosial perusahaan, sehingga merupakan komitmen dari perseroan untuk berperan serta dalam pembangunan ekonomi berkelanjutan.

Pengaturan masalah sanksi hukum atas pelaksanann CSR ini di satu sisi merupakan suatu kemajuan karena aturan tentang tanggungjawab sosial dan lingkungan ini merupakan hal yang baru yang bersifat memaksa para pelaku usaha untuk melaksanakan CSR ini. Adanya ketentuan sanksi hukum ini perusahaan dituntut untuk memiliki tanggungjawab sosial yang tidak hanya berdasarkan kedermawanan perusahaan tersebut atau berdasarkan moralKegiatan dilaksanakan bersama-sama dengan masyarakat dan pihak lain yang memiliki kompetensi yang tepat; semata, tetapi sudah merupakan kewajiban bagi perusahaan dalam menjalankan kegiatan bisnisnya untuk menjaga terjadinya relasi sosial yang harmonis dan menjaga agar lingkungan tidak menjadi rusak, dan apabila tidak dilaksanakan akan dikenai sanski sesuai dengan ketentuan Pasal 74 ayat (3) UU PT.

Konsep CSR oleh Pasal 74 ayat (1) UU PT telah ditetapkan sebagai kewajiban hukum dan harus dilaksanakan. Dimasukkannya konsep CSR dalam ketentuan Pasal 74 UU PT tersebut merupakan suatu langkah maju bagi kepentingan masyarakat, bangsa dan negara walaupun ketentuan pasal tersebut diberlakukan secara terbatas bagi perusahaan yang menjalankan kegiatan usahanya di bidang sumber daya alam. Adanya ketentuan Pasal 74 UU PT dan PP 
yang mengatur tentang tanggungjawab sosial dan lingkungan ini (CSR) ini tidak akan berhasil apabila tidak diatur mengenai sanksinya.

Mengingat dalam kedua aturan tersebut tidak diatur mengenai sanksi atas tidak dilaksanakannya $C S R$ tersebut yang akan berimbas pada banyaknya perusahaan yang akan mengabaikan ketentuan CSR ini apabila tidak ada aturan yang memaksanya. Oleh karena itu, ketentuan Pasal 74 ayat (3) UU PT ini tidak akan mempunyai arti apabila belum adanya peraturan yang mengatur secara tegas apa wujud dari sanksi ketentuan tersebut, begitu pula ketentuan PP 47 Tahun 2012 yang tidak mengatur secara jelas ketentuan tentang wujud sanski atas tidak dilaksanakannya $C S R$ ini akan menjadi masalah dalam mengimplementasikan ketentuan CSR ini dalam praktek..

Tentang hal ini menurut penulis penyerahan CSR kepada pemerintah daerah untuk dikelola dan integrasikan dalam APBD daerah adalah merupakan hal yang bertentangan dengan hakekat CSR itu sendiri. Program CSR dimaksud untuk membantu masyarakat disektar wilayah perusahaan yang mengelolah sumber daya alam yang tentunya dalam hal ini terkena dampak langsung $\mathrm{d}$ ari kegiatan tersebut. Disanping itu dimaksudkan agar masyarakat disekitar wilayah perusahaan merasah turut memiliki terhadap perusahaan tersebut.Pemahaman bahwa CSR merupakan hak penuh dari pemerintah daerah merupakan suatu intervensi pemerintah daerah terhadap perusahaan yang ada di wilayahnya. Jika CSR dikelolah oleh Pemda, maka besar kemungkinan sasaran dari CSR tidak tercapai, dan rentan penyalagunaan dana CSR oleh pemeritah daerah.

Selain itu, usulan mengintegrasikan CSR dalam APBD sedikit bertentangan dengan program CSR sebagai strategi bisnis perusahaan. Meski terdengar negatif, program CSR yang diselenggarakan perusahaan di Indonesia bermanfaat bagi masyarakat. Praktik di berbagai negara, CSR merupakan program kesukarelaan yang saling menguntungkan antara perusahaan dan masyarakat.

Menurut penulis langkah yang paling bijaksana adalah CSR sebenarnya bisa dikoordinasikan oleh pemerintah asal perencanaannya jelas. Pemerintah atau Pemda harus punya rencana strategis yang terukur. "Ini program pengentasan kemiskinan di daerah A. Dana dari pajak sekian, dari pemerintah pusat sekian, 
perusahaan diminta menutupi kekurangannya," Dengan cara seperti itu, penulis yakin perusahaan akan senang bekerja sama dengan pemerintah. "Tidak perlu diwajibkan pun perusahaan akan berpartisipasi aktif. Tapi sifatnya koordinasi,"

Terkait dengan Pertanggungjawaban Hukum atau Liability terhadap perusahaan yang tidak melaksanakan CSR sebagaimana diatur dalam pasal 74 UU PT, tidak dicantumkan secara eksplisit pertanggungjawaban hukum seperti apa yang akan dibebankan kepada perusahaan. Namun demikian, dalam undangundang itu pula dijelaskan bahwa perusahaan dapat dipertanggungjawabkan secara hukum berdasarkan peraturan perundang-undangan terkait misalnya; KUH Perdata, UU Lingkungan Hidup, UU Perlindungan Konsumen, UU Pertambangan, dan sebagainya.

Kewajiban atas tanggung jawab sosial dan lingkungan bagi perusahaan yang telah ditetapkan sebagai kewajiban hukum oleh UU PT ini mempunyai implikasi agar kewajiban perusahaan atas lingkungan sekitarnya tidak hanya sebatas dalam tataran moralitas yang pelaksanaannya bersifat sukarela semata, tetapi perlu diatur dalam suatu norma hukum sebagai suatu kewajiban hukum agar tercapai suatu kepastian hukumnya.

Implementasi CSR ini seyogyanya memberikan manfaat yang sebesarbesarnya baik bagi internal maupun eksternal perusahaan, sehingga filosofi pemberian CSR itu sendiri tercapai. Menurut Sutan Remy Sjahdeini, terkait dengan tujuan atau manfaat pelaksanaan CSR menyatakan, pelaksanaan CSR telah meningkatkan reputasi perusahaan, reputasi yang baik itu memudahkan perusahaan untuk dapat melakukan rekrutmen pegawai yang berkualitas dan bereputasi baik, para pegawai lebih betah untuk bekerja di perusahaan yang melaksanakan $C S R$ sehingga perusahaan dapat mengurangi biaya yang timbul karena harus melakukan rekrutmen baru dan melakukan pelatihan bagi pegawai pegawai baru itu dan sebagainya ${ }^{21}$

21 Ibid, h.64. 


\section{SIMPULAN}

Pengaturan konsep CSR oleh Pasal 74 ayat (1) UU PT telah ditetapkan sebagai kewajiban hukum dan harus dilaksanakan. Dimasukkannya konsep CSR dalam ketentuan Pasal 74 UU PT tersebut merupakan suatu langkah maju bagi kepentingan masyarakat, bangsa dan negara walaupun ketentuan pasal tersebut diberlakukan secara terbatas bagi perusahaan yang menjalankan kegiatan usahanya di bidang sumber daya alam. Hal-Hal yang Menjadi Kendala dalam pelaksanaan CSR selama ini karena hanya didasarkan kepada kesadaran dan komitmen perusahaan. Padahal komitmen dan kesadaran setiap perusahaan tidak sama dan sangat tergantung sekali kepada kebijakan perusahaan masing-masing.

\section{DAFTAR PUSTAKA}

Departemen Hukum dan HAM, 2010, "Tanggung Jawab Sosial Perusahaan (Corporate social Responsibility) dan Iklim Penanaman Modal", Available from: http://www.djpp.depkumham.go.id/index.php/jurnal-legislasi

Fuady, Munir 2002, Doktrin-doktrin Modern dalam Corporate Law dan Eksistensinya dalam Hukum Indonesia, Citra Aditya Bakti, Bandung

I Gusti Ngurah Anom "Pengembangan Tanggung Jawab Sosial Perseroan (Corporate Social Responsibility) Dikaitkan Dengan Konsep Tri Hita Karana (Studi di Provinsi Bali)"

Prasetya, Rudhi, 1996, Kedudukan Mandiri Perseroan Terbatas, Citra Aditya Bakti, Bandung

Renny Syahdeni, Sutan, 2006: Pertanggungjawaban Pidana Korporasi, Grafiti Pers, Jakarta

Septina Basani, Christin, 2007, Peran Perusahaan Sebagai Agen Perubahan Pelaksanaan Tanggung Jawab Sosial (Corporate Social Responsibility), Tesis pada Program Magister Kenotariatan Universitas Gadjah Mada Yogyakarta

Solihin, Ismail, 2009, Corporate Social Responsibility: from Charity to Sustainability,Salemba Empat, Jakarta, 
Supasti, Ni Ketut Dharmawan, 2009, A Hybrid Framework, Suatu Alternative Pendekatan CSR (Corporate Social Responsibility) Di Indonesia, Makalah pada Diseminasi Tentang Rekomendasi Bagi Pembaharuan Hukum di Indonesia, Denpasar,

Susanto, A.B, 2007, Corporate Social Responsibility, The Jakarta Consulting Group, Jakarta, 